\title{
On-farm effects of no-till versus occasional tillage on soil quality and crop yields in eastern Ohio
}

\author{
I. Stavi $\cdot$ R. Lal $\cdot$ L. B. Owens
}

Accepted: 26 July 2010 /Published online: 25 February 2011

(C) INRA and Springer Science+Business Media B.V. 2011

\begin{abstract}
Contrary to earlier studies, this study suggests that even one year of tillage within a long-term no-till agroecosystem adversely affected the soil quality, with possible negative impact on crop yields. Worldwide interest in conservation tillage is increasing, because conventional tillage adversely impacts the long-term quality of the soil and its vulnerability to erosion. No-till agriculture minimizes adverse impacts of an intensive arable land use. In some cases, occasional tillage is used as a means of weed or pathogen control. Therefore, this study was conducted in eastern Ohio to examine soil quality as affected by occasional tillage, i.e. disk plowed every $3-4$ years, within a long-term no-till agroecosystem. The study compared the soil characteristics between two fields, both under corn (Zea mays L.) at the time of the study. Soil properties were studied for three depths of $0-6,6-12$, and $12-18 \mathrm{~cm}$. Compared with the continuous no-till field, the field under occasional tillage had significantly higher bulk density of 1.45 versus $1.31 \mathrm{~g} \mathrm{~cm}^{-3}$, and somewhat higher soil penetration resistance of 1.77 versus $1.56 \mathrm{MPa}$. Also, compared with the no-till field, the field under occasional tillage had significantly lower water stable aggregate of 475 versus $834 \mathrm{~g} \mathrm{~kg}^{-1}$, mean weight diameter of 1.4 versus $3.4 \mathrm{~mm}$, field moisture capacity of 293 versus $360 \mathrm{~g} \mathrm{~kg}^{-1}$, equilibrium infiltration rate of 2.0 versus $6.7 \mathrm{~mm} \mathrm{~min}^{-1}$,
\end{abstract}

\footnotetext{
I. Stavi $(\bowtie) \cdot$ R. Lal

Carbon Management and Sequestration Center,

The Ohio State University,

Columbus, OH 43210, USA

e-mail: istavi@yahoo.com

L. B. Owens

USDA-ARS, North Appalachian Experimental Watershed,

Coshocton, OH 43812, USA
}

and cumulative infiltration of 353.4 versus $1,211.8 \mathrm{~mm}$. The field under occasional tillage had somewhat lower soil organic carbon of 16.0 versus $19.2 \mathrm{~g} \mathrm{~kg}^{-1}$, soil water sorptivity of 16.3 versus $36.5 \mathrm{~mm} \mathrm{~min}^{-0.5}$, and transmissivity of 2.1 versus $4.9 \mathrm{~mm} \mathrm{~min}^{-1}$. The occasional tillage had no effect on the soil shear strength. In general, the effect of tillage on soil properties decreased with increase in soil depth. Also corn yields were compared between the two agroecosystems. Compared with the no-till field, the field under occasional tillage had significantly lower grain moisture content of 22.4 versus $28.2 \%$, and somewhat lower wet stover biomass of 14.6 versus $20.2 \mathrm{Mg} \mathrm{ha}^{-1}$, wet corn ear yield of 10.0 versus $11.4 \mathrm{Mg} \mathrm{ha}^{-1}$, and dry grain yield of 8.2 versus $9.4 \mathrm{Mg} \mathrm{ha}^{-1}$. As contrasted with earlier studies which were conducted under controlled research plots, this study was conducted under on-farm conditions.

Keywords Field moisture capacity · Soil aggregation · Soil organic carbon · Sustainable farming · Tillage system · US corn belt . Water infiltrability

\section{Introduction}

Tillage of agricultural lands considerably affects a range of the soil characteristics, thus, it impacts the availability of resources for crop growth. No-till practices reduce the adverse impacts of tillage by increasing the soil aggregation process and by sequestering soil organic carbon ( $\mathrm{Lal}$ et al., 2004). Thus, structural stability and quality of the soil are improved (Cassel et al., 1995; Moebius-Clune et al., 2008). The increased soil organic carbon concentration also enhances microbial productivity and soil fertility, while the increased soil stability reduces its erodibility by water (Lal et al., 2004). 
Numerous studies have compared the effects of tillage and no-till agroecosystems on soil physical and hydrological characteristics with respect to short-term (3-7 years, Bono et al., 2008; Martinez et al., 2008) and long-term (1030 years, Blanco-Canqui et al., 2006; Moebius-Clune et al., 2008) impacts. However, there are few studies which have investigated the effects of occasional tillage, and more specifically its short-term impacts on soil properties. Yet, occasional tillage is increasingly being used in the US Corn Belt region. This is due to favorable impact of such tillage to control pathogen infestations (Pierce et al., 1994) or the spreading of winter weeds, while maintaining many of the soil quality benefits of conservation tillage management (Kettler et al., 2000). Thus, the major objective of the present study was to compare key indicators of the soil quality between two tillage systems: ten consecutive years of no-till, and occasional tillage. The secondary objective was to examine the impact of tillage system on crop yields. It was hypothesized that compared with the no-till agroecosystem, the field under occasional tillage was not susceptible to adverse impacts on soil quality and crop yields because of the low frequency of tillage.

\section{Materials and methods}

\subsection{Site description}

The study was conducted on two private farms at a rural area $\left(40^{\circ} 26^{\prime} 35^{\prime \prime} \mathrm{N}, 81^{\circ} 45^{\prime} 24^{\prime \prime} \mathrm{W}\right)$ in Coshocton County, Ohio. Average temperatures in the winter and summer are -2.7 and $21.1^{\circ} \mathrm{C}$, respectively. Mean annual precipitation is $94 \mathrm{~cm}$, of which $56 \mathrm{~cm}$ is received between April and September. Thunderstorms occur on $\sim 40$ days a year, most during summer. These storms are usually intense, but are local in extent and of short duration. Winter precipitation, frequently snow, results in a considerable storage of soil moisture by spring. The average seasonal snowfall is $76 \mathrm{~cm}$ and $\sim 15$ days in a year have at least $2.5 \mathrm{~cm}$ of snow on the ground. The growing season for most crops is between April and September. Topography is characteristically rolling hills, with intermediate to moderate hill slopes (USDA-NRCS, 2002). Bedrock is characterized by many thin layers of shale, sandstone, limestone, coal, and clay that are interbedded between two prominent sandstone beds. The upper sandstone bed caps the highest ridges, whereas the lower bed embraces the steep lower slopes and underlies the valley floor. This complex geologic bed affects the formation of crossword puzzle-like pattern of more than half a dozen of different soil series (Kelley et al., 1975).

Two fields, one in each farm, were selected for the experiment, both under corn (Zea mays L.) at the end of the 2008 growing season. Corn was at the same phenological stage (full maturity) in both fields. In the no-till field, granular fertilizer was applied prior to planting at a rate of $200 \mathrm{~kg} \mathrm{Nha}{ }^{-1}$. The long-term strategy of this field was continuous no-tillage coupled with crop residue management, in order to control soil erosion. The occasional tillage field received unprocessed poultry manure at a rate of 5$10 \mathrm{Mg} \mathrm{ha}^{-1}$, and disked to $15-\mathrm{cm}$ depth before planting. The long-term farming system of the field was based on a rotation of three to five consecutive years of no-till followed by 1 year of disking. The long-term rotation was followed to control incidence of weeds and pathogens. Management practices for both fields are detailed in Table 1. The rationale for selecting these two fields includes the following: (1) same crop at the time of the study; (2) a relatively similar cropping history; (3) similar slope gradient, $3^{\circ}$ for the occasional tillage field and $2^{\circ}$ for the no-till field; and (4) Coshocton soil series (fine loamy, mixed, active, mesic Aquultic Hapludalfs) in both fields.

Three plots $(10 \times 10 \mathrm{~m}$ each) were randomly selected in each field, with at least $200 \mathrm{~m}$ distance among them. The
Table 1 Management practices' history according to treatment

$(+)$ Occurred, (-) not occurred

${ }^{\mathrm{a}}$ Chemical granular fertilizer at a rate of $200 \mathrm{~kg} \mathrm{Nha}^{-1}$ before planting

${ }^{\mathrm{b}}$ Application of unprocessed poultry manure $\left(5-10 \mathrm{Mg} \mathrm{ha}^{-1}\right)$ before planting.

\begin{tabular}{|c|c|c|c|c|c|c|}
\hline \multirow[t]{2}{*}{ Year } & \multicolumn{2}{|l|}{ Crop } & \multicolumn{2}{|l|}{ Tillage } & \multicolumn{2}{|c|}{ Fertilizing } \\
\hline & No till & Occasional tillage & No till & Occasional tillage & No till & Occasional tillage \\
\hline 2008 & Corn & Corn & No tillage & Disk plowing & $t^{\mathrm{a}}$ & $+^{\mathrm{b}}$ \\
\hline 2007 & Soybean & Corn & No tillage & No tillage & $+^{\mathrm{a}}$ & - \\
\hline 2006 & Soybean & Alfalfa- hay & No tillage & No tillage & $+^{\mathrm{a}}$ & - \\
\hline 2005 & Corn & Oats & No tillage & No tillage & - & $+^{\mathrm{b}}$ \\
\hline 2004 & Pastures-hay & Corn & No tillage & Disk plowing & - & - \\
\hline 2003 & Pastures-hay & Pastures-hay & No tillage & No tillage & - & - \\
\hline 2002 & Pastures-hay & Pastures-hay & No tillage & No tillage & - & - \\
\hline 2001 & Pastures-hay & Pastures-hay & No tillage & No tillage & - & - \\
\hline 2000 & Pastures-hay & Pastures-hay & No tillage & No tillage & - & - \\
\hline 1999 & Pastures-hay & Pastures-hay & No tillage & No tillage & - & - \\
\hline
\end{tabular}


usage of one field for each tillage treatment stemmed from the very high spatial and temporal heterogeneity, which eliminated the ability to control the above mentioned 1-4 factors. Despite the limitation of this approach in terms of statistical analysis, under the prevailing highly heterogeneous spatial and temporal conditions, using pseudoreplication design was the only possible means of assessing the effects of tillage treatment on the soil characteristics. A similar statistical approach was successfully used in prior studies for assessing various soil physical characteristics (Shukla and Lal, 2005b) and soil organic carbon dynamics (Shukla and Lal, 2005a) after conversion from tillage to no-till.

\subsection{Procedures}

Initial observations in the no-till and the occasional tillage fields indicated no apparent soil erosion, by either inter-rills or rills. In the occasional tillage field, however, soil surface had a mechanical crust of $\sim 0.5-1 \mathrm{~mm}$ thicknesses. There was no visible crust in the no-till field.

Field work was conducted during autumn (September) 2008. Three sites were randomly selected in the inter-row spaces of each plot $(n=18)$ to conduct the water infiltration test. Water infiltrability was measured by using a doublering infiltrometer, with inner and outer rings' diameter of 15 and $27 \mathrm{~cm}$, respectively (Reynolds et al., 2002). The change in water head in the inner cylinder was measured over a period of $3 \mathrm{~h}$ at $1,3,6,10,15,30,45,60,90,120$, 150 , and $180 \mathrm{~min}$. A head of $5-10 \mathrm{~cm}$ was maintained throughout the experiment. Data were analyzed by using Philip's model (Philip 1957):

$I=S t^{0.5+} A t$

where, $I$ is cumulative infiltration $(\mathrm{mm}), S$ is soil water sorptivity $\left(\mathrm{mm} \min ^{-0.5}\right), A$ is transmissivity $\left(\mathrm{mm} \mathrm{min}^{-1}\right)$, and $t$ is time ( $\mathrm{min})$.

The infiltration rate $i\left(\mathrm{~mm} \mathrm{~min}^{-1}\right)$ was computed by the equation:

$i=d I / d T=0.5 S t^{-0.5}+A$

The equation was used to compute also the following parameters:

- $S$ : slope of the regression line when plotting $t^{0.5}$ against $i$;

- $A$ : intercept of $t 0$ by the regression line when plotting $t^{0.5}$ against $i$;

- Equilibrium infiltration rate (if: $\mathrm{mm} \mathrm{min}^{-1}$, at $180 \mathrm{~min}$ )

- Cumulative infiltration (Ic: $\mathrm{mm}$, at $180 \mathrm{~min}$ )

Following the completion of the test, soil was covered with a plastic sheet to prevent evaporation. Soil moisture content was measured $24 \mathrm{~h}$ later at three depths $(0-6,6-12$, and $12-18 \mathrm{~cm})$ in these sites $(n=54)$ to assess the field moisture capacity.

Seven additional sites were randomly selected in the inter-row spaces of each plot and soil was sampled at three depths: $0-6,6-12$, and $12-18 \mathrm{~cm}(n=126)$. A core of $54 \mathrm{~mm}$ diameter and $60 \mathrm{~mm}$ height was obtained at each depth to measure the soil bulk density (Grossman and Reinsch, 2002). In addition, bulk soil ( $\sim 500 \mathrm{~g})$ sample was taken to measure concentrations of soil organic carbon (the dry combustion method $\left[900^{\circ} \mathrm{C}\right]$ using a $\mathrm{CN}$ analyzer [Vario Max, Elementar Americas, Mount Laurel, NJ]; Nelson and Sommers, 1996), and soil aggregation (the wet sieving method; Nimmo and Perkins, 2002). The latter test was conducted by using the aggregate size range of $4.75-8 \mathrm{~mm}$. The air-dried aggregates were placed on top of a set of sieves of $4.75,2,1,0.5$, and $0.25-\mathrm{mm}$ mesh size (from the upper edge to the bottom). The set of sieves with the aggregates were allowed wet slowly for $30 \mathrm{~min}$. Then, the wet sieving operation was conducted for another $30 \mathrm{~min}$. The soil from each sieve was put in a beaker, dried, and weighed to enable the calculation of the mean weight diameter of aggregates and the percentage of water stable aggregates.

Soil penetration resistance at three depths $(0-6,6-12$, and $12-18 \mathrm{~cm}$ ) was measured at four randomly selected locations in the vicinity of each soil sampling site, by using a hand-held penetrometer (Findlay Irvine Ltd, Midlothian, Scotland). Similarly, vane shear strength was measured at seven randomly selected locations in the vicinity of each soil sampling site, by using a vane shear tester (Eijkelkamp, Giesbeek, the Netherlands). On each site, four or seven values of the soil penetration resistance or shear strength, respectively, were averaged and the mean values were used for the statistical analysis. Thus, number of replicates $(n)$ was 126 for penetration resistance and 42 for vane shear strength.

In addition, at a distance of $\sim 5 \mathrm{~m}$ from any of these plots, another plot comprised of two rows was harvested along $2 \mathrm{~m}$ to assess several plant growth and agronomic indices. These indices included:

1. Wet stover biomass $(\mathrm{Mg})$ : including above-ground vegetative, but excluding reproductive biomass, weighted in situ following harvest

2. Wet corn ear yield $(\mathrm{Mg})$ : including all reproductive biomass, weighted in situ following harvest

3. Dry grain yield $(\mathrm{Mg})$ : weight of grain after drying for $24 \mathrm{~h}$ at $65^{\circ} \mathrm{C}$

4. Grain moisture content $(\%)=($ wet grain yield - dry grain yield) $\times 100 /$ dry grain yield

For any of the above 1-3 indices, total biomass or yield of each plot was averaged. These plot data were used to 
calculate biomass or yield per hectar. These values were used for the quantitative analysis. Total number of plots $(n)$ for any of the above 1-4 indices was six.

\subsection{Statistical analysis}

The factorial experiment design was used for the analysis of the measured variables. Analysis of variance (ANOVA) was conducted with the general linear model (GLM) procedure of SAS (SAS Institute, 1990). Factors in the model for vane shear strength and the water infiltrability indices were: treatment $(1 d f)$ and plot within treatment $(4 d f$; error term for treatment). Factors in the model for the remainder of the soil quality indices were: treatment $(1 d f)$, plot within treatment ( $4 d f$, error term for treatment), depth $(2 d f)$, and the interaction of depth $\times$ treatment $(2 d f)$. The factor in the model for the crop yield indices was treatment $(1 d f)$. Statistically significant interactions were subjected to further ANOVA with the SLICE command of PROC GLM. Separation of means was conducted by Tukey's HSD at the 0.05 probability level.

Pearson correlation coefficients were calculated to examine the relationships between soil properties. This examination was conducted only between characteristics of the soil sampled at the same sites (i.e., bulk density, water stable aggregates, mean weight diameter of aggregates, and soil organic carbon concentration).

\section{Results and discussion}

\subsection{Soil physical characteristics}

One year of tillage following three years of no-tillage caused considerable degradation of the mechanical features of the soil surface, as indicated by the increase in crust cover. Also, the occasional tillage adversely affected the mean soil penetration resistance, and significantly affected the mean soil bulk density, water stable aggregates content, and mean weight diameter of aggregate. However, tillage treatment had no effect on the mean vane shear strength
(Table 2). Soil depth significantly affected the mean values of the soil penetration resistance, bulk density, water stable aggregates content, and mean weight diameter of aggregate (Table 3). Differences between the two tillage treatments were generally larger for the shallowest depth than for the middle and deepest depths (Table 4).

The increased soil bulk density in the occasional tillage field corresponds with Kettler et al. (2000), who reported increased bulk density in $0-7.5 \mathrm{~cm}$ depth following occasional tillage, and attributed this change to decreased soil organic carbon concentration in this layer. However, the increased bulk density under this treatment in our study was not in accord with Pierce et al. (1994), who reported that periodical plowing decreased soil bulk density in the $0-15 \mathrm{~cm}$ depth. Also, the reduced water stable aggregates content in the occasional tillage field did not correspond with Quincke et al. (2007b) who observed no effect of occasional tillage on this soil characteristic.

\subsection{Surface hydrology}

The occasional tillage adversely affected all the soil hydraulic features. The mean infiltration rate was significantly higher in the no-till field at all time intervals (Fig. 1). The mean sorptivity and transmissivity were somewhat higher in the no-till field, and the mean equilibrium infiltration rate and cumulative infiltration were significantly higher under this treatment (Fig 2). The decreased infiltration rate and sorptivity in the occasional tillage field only partially correspond with an eastern Nebraska study (Quincke et al., 2007b), where occasional tillage positively affected the water infiltration rate and negatively affected the soil water sorptivity. In another study site in eastern Nebraska, Quincke et al. observed that occasional tillage reduced both infiltration rate and sorptivity. These observations emphasize the site-dependant effects of occasional tillage on soil characteristics.

The observed modifications in soil physical and hydrological properties by the occasional tillage did not accelerate soil erosion. There were no visible signs of inter-rill or rill erosion under this tillage treatment. Furthermore, there
Table 2 Treatment effect on the soil characteristics

Means within a row followed by different letters differ at the 0.05 probability level according to Tukey's HSD

\begin{tabular}{lllll}
\hline Level & Units & $P$ value & No till & Occasional tillage \\
\hline Penetration resistance & $\mathrm{MPa}$ & 0.4673 & $1.56 \mathrm{a}$ & $1.77 \mathrm{a}$ \\
Vane shear strength & $\mathrm{kPa}$ & 0.8383 & $173.6 \mathrm{a}$ & $171.0 \mathrm{a}$ \\
Bulk density & $\mathrm{g} \mathrm{cm}^{-3}$ & 0.0395 & $1.31 \mathrm{~b}$ & $1.45 \mathrm{a}$ \\
Water stable aggregates content & $\mathrm{g} \mathrm{kg}^{-1}$ & 0.0001 & $834 \mathrm{a}$ & $475 \mathrm{~b}$ \\
Mean weight diameter of aggregate & $\mathrm{mm}$ & 0.0040 & $3.4 \mathrm{a}$ & $1.4 \mathrm{~b}$ \\
Field moisture capacity & $\mathrm{g} \mathrm{kg}^{-1}$ & 0.0026 & $360 \mathrm{a}$ & $293 \mathrm{~b}$ \\
Soil organic carbon concentration & $\mathrm{g} \mathrm{kg}^{-1}$ & 0.1966 & $19.2 \mathrm{a}$ & $16.0 \mathrm{a}$ \\
\hline
\end{tabular}


Table 3 Depth effect on the soil characteristics

Means within a row followed by different letters differ at the 0.05 probability level according to Tukey's HSD

\begin{tabular}{llllll}
\hline Level & Units & $P$ value & Shallow & Middle & Deep \\
\hline Penetration resistance & $\mathrm{MPa}$ & 0.0001 & $0.84 \mathrm{c}$ & $1.65 \mathrm{~b}$ & $2.52 \mathrm{a}$ \\
Bulk density & $\mathrm{g} \mathrm{cm}^{-3}$ & 0.0001 & $1.30 \mathrm{c}$ & $1.40 \mathrm{~b}$ & $1.44 \mathrm{a}$ \\
Water stable aggregates content & $\mathrm{g} \mathrm{kg}^{-1}$ & 0.0003 & $674 \mathrm{a}$ & $668 \mathrm{a}$ & $621 \mathrm{~b}$ \\
Mean weight diameter of aggregate & $\mathrm{mm}^{\text {Field moisture capacity }}$ & 0.0001 & $2.8 \mathrm{a}$ & $2.4 \mathrm{~b}$ & $2.1 \mathrm{c}$ \\
Soil organic carbon concentration & $\mathrm{g} \mathrm{kg}^{-1}$ & 0.0001 & $387 \mathrm{a}$ & $308 \mathrm{~b}$ & $285 \mathrm{~b}$ \\
& $\mathrm{~g} \mathrm{~kg}^{-1}$ & 0.0001 & $20.4 \mathrm{a}$ & $17.3 \mathrm{~b}$ & $15.1 \mathrm{c}$ \\
\hline
\end{tabular}

was no effect of tillage on vane shear strength. This is attributed to the nature of the mechanical crusts, which had almost complete cover in the occasional tillage field. Crust formation is affected by raindrop impact and by aggregate breakdown due to rapid wetting (Fan et al., 2008). These lead, simultaneously, to physical compaction and compression and pore filling by fine material in the soil surface (Bajracharya, 1995). Thus, mechanical crusts reduce water infiltrability (Wells et al., 2003) and enhance overland flow (Zeiger and Fohrer, 2009), and are expected to increase soil erosion (Blanco-Canqui and Lal, 2007). However, in the present study, despite not directly monitoring erosional processes, the crust seemed to reduce the susceptibility of the soil to erosion. This was indicated by both of the relatively high vane shear strength and by the absence of signs for rill and interill erosion on the surface of the occasional tillage field. These results are in accord with those reported by Neave and Rayburg (2007), who noted that crust formation increased the shear strength of the soil by creating a protective layer of dense material that is highly resistant to erosion. Bradford et al. (1986) reported that the formation of a mechanical crust also reduces the detachment of soil particles by raindrop impact.

The mean value of field moisture capacity in the occasional tillage field was significantly reduced compared with that in the no-till field (Table 2). Depth had a highly significant effect on the field moisture capacity, which was significantly larger for the shallowest depth than for the middle and deepest depths (Table 3). The interaction between depth and treatment had no significant effect on the field moisture capacity, but within each depth, the notill field had a larger value than that in the occasional tillage field (Table 4). Although neither field experienced severe drought stress, it is likely that the low water infiltrability and field moisture capacity in occasional tillage field compared with the no-till field may exacerbate drought impact in prolonged rainless periods.

\subsection{Soil organic carbon concentration}

Although treatment had no significant effect on soil organic carbon, its mean value was somewhat higher in the no-till field than that in the occasional tillage field (Table 2). Depth had a highly significant effect on SOC concentration, and it differed significantly among all depths, being the highest and lowest for the shallowest and deepest depths, respectively (Table 3). Despite that treatment had no significant effect on the soil organic carbon concentration, the interaction between depth and treatment had a highly significant effect on this variable. Compared with the no-till field, the soil organic carbon concentrations in the field under occasional tillage was significantly $(P<0.0001)$ lower in the shallowest depth, somewhat lower $(P=0.1242)$ in the middle depth, and slightly higher $(P=0.4484)$ in the deepest depth (Table 4).

The significant effect of tillage treatment on the soil organic carbon concentration in the shallower depth may be attributed to the high sensitivity of the uppermost soil

Table 4 The soil characteristics associated with the combinations of treatment and depth

\begin{tabular}{|c|c|c|c|c|c|c|c|c|}
\hline \multirow[t]{2}{*}{ Level } & \multirow[t]{2}{*}{ Units } & \multirow[t]{2}{*}{$P$ value } & \multicolumn{3}{|l|}{ No-till } & \multicolumn{3}{|c|}{ Occasional tillage } \\
\hline & & & Shallow & Middle & Deep & Shallow & Middle & Deep \\
\hline Penetration resistance & $\mathrm{MPa}$ & 0.0001 & $0.42 \mathrm{c}$ & $1.57 \mathrm{~b}$ & $2.69 \mathrm{a}$ & $1.25 \mathrm{~b}$ & $1.73 \mathrm{~b}$ & $2.35 \mathrm{a}$ \\
\hline Bulk density & $\mathrm{g} \mathrm{cm}^{-3}$ & 0.0009 & $1.20 \mathrm{~d}$ & $1.35 \mathrm{c}$ & $1.39 \mathrm{bc}$ & $1.40 \mathrm{bc}$ & $1.44 \mathrm{ab}$ & $1.50 \mathrm{a}$ \\
\hline Water stable aggregates content & $\mathrm{g} \mathrm{kg}^{-1}$ & 0.0002 & $887 \mathrm{a}$ & 838 a & $776 \mathrm{~b}$ & $461 \mathrm{c}$ & $497 \mathrm{c}$ & $466 \mathrm{c}$ \\
\hline Mean weight diameter of aggregate & $\mathrm{mm}$ & 0.0001 & $4.3 \mathrm{a}$ & $3.3 \mathrm{~b}$ & $2.7 \mathrm{c}$ & $1.3 \mathrm{~d}$ & $1.6 \mathrm{~d}$ & $1.5 \mathrm{~d}$ \\
\hline Field moisture capacity & $\mathrm{g} \mathrm{kg}^{-1}$ & 0.6108 & $431 \mathrm{a}$ & $334 \mathrm{bc}$ & $315 \mathrm{bc}$ & $343 \mathrm{~b}$ & $282 \mathrm{bc}$ & $256 \mathrm{c}$ \\
\hline Soil organic carbon concentration & $\mathrm{g} \mathrm{kg}^{-1}$ & 0.0001 & $24.9 \mathrm{a}$ & $18.2 \mathrm{~b}$ & $14.7 \mathrm{c}$ & $15.9 \mathrm{bc}$ & $16.4 \mathrm{bc}$ & $15.6 \mathrm{bc}$ \\
\hline
\end{tabular}

Means within a row followed by different letters differ at the 0.05 probability level according to Tukey's HSD 
Fig. 1 Mean infiltration rate according to treatment

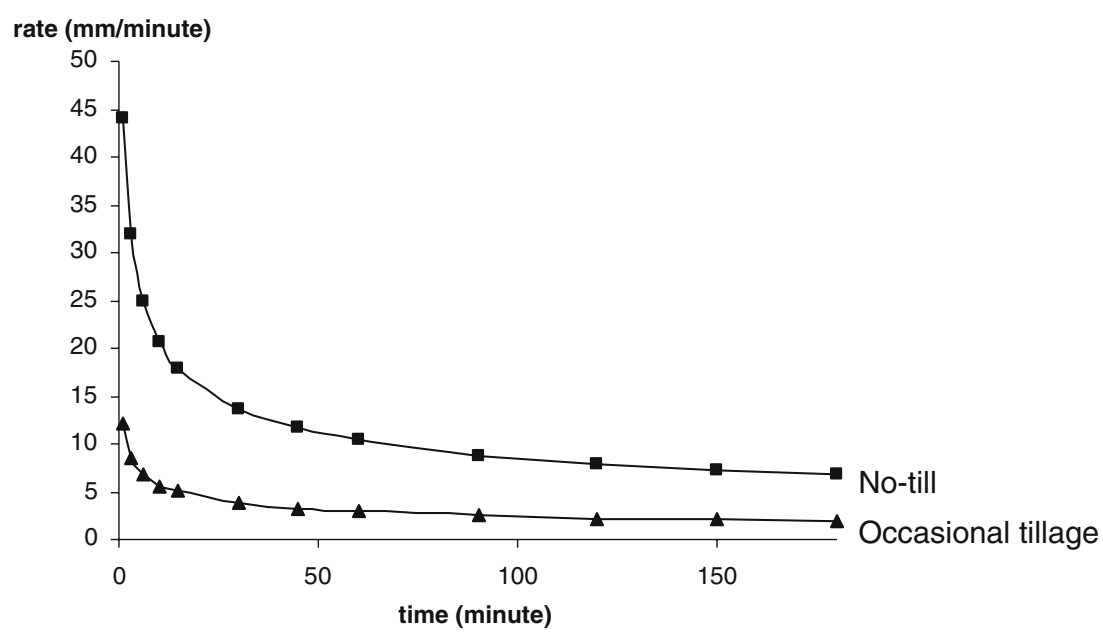

horizon to tillage, because the largest accumulation of organic residues in this layer. In their study in eastern Nebraska, Quincke et al. (2007a) investigated the impact of various tillage systems on soil organic carbon dynamics. They reported that occasional tillage following 10 years of continuous no-tillage resulted in redistribution of the soil organic carbon in the soil profile. Twenty-four to 32 months after tillage, they observed that some of the tillage systems reduced the soil organic carbon concentration by $24-88 \%$ in the $0-2.5 \mathrm{~cm}$ depth, but increased it by $13-381 \%$ in the $5-$ $10 \mathrm{~cm}$ depth. They attributed these changes to the vertical redistribution of soil organic carbon caused by inversion tillage. In the same study they detected an increased carbon dioxide flux immediately after disking or chisel tillage. However, in general, they found no significant loss of soil organic carbon stock 24-32 months after tillage. In another

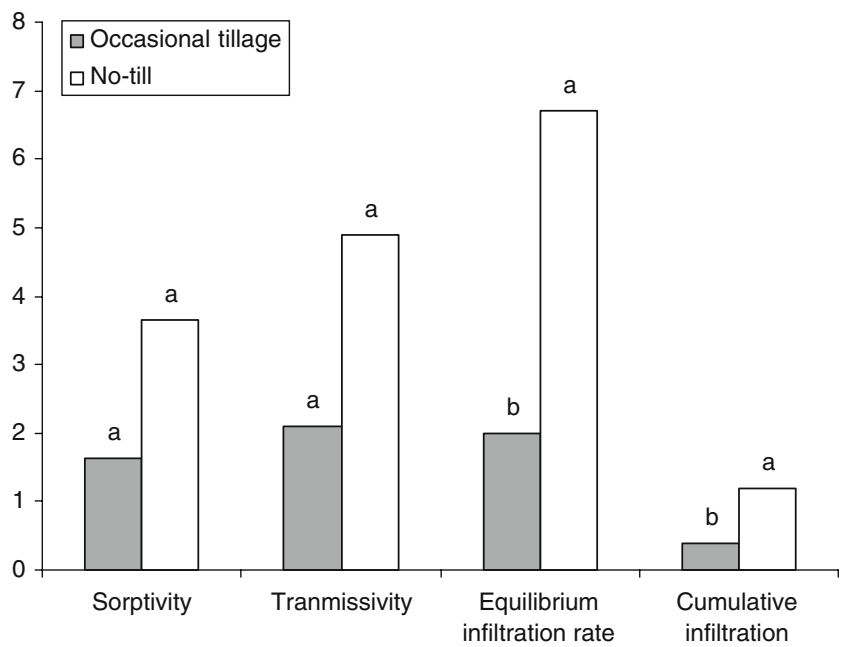

Fig. 2 Mean values of the soil sorptivity $\left(\mathrm{cm} \mathrm{min}^{-0.5}\right)$, transmissivity $\left(\mathrm{mm} \min ^{-1}\right)$, equilibrium infiltration rate $\left(\mathrm{mm} \mathrm{min}^{-1}\right)$ and cumulative infiltration $(\mathrm{m})$ according to treatment. Means within a pair of bars followed by different letters differ at the 0.05 probability level according to Tukey's HSD study in Nebraska, Kettler et al. (2000) reported that 5 years after moldboard tillage in a prolonged no-till system, the soil organic carbon concentration decreased in 0-7.5 $\mathrm{cm}$ depth, but increased in 7.5-15 cm depth. Similar findings were also observed in Michigan by Pierce et al. (1994), who reported a redistribution of soil organic carbon concentration through the tilled layer following occasional plowing. In the present study, the significantly reduced soil organic carbon concentration in the 0-6 $\mathrm{cm}$ depth following disking was not accompanied with an increase in the 6-12 and $12-18 \mathrm{~cm}$ depths. Thus, despite being not significant, the total reduction of soil organic carbon concentration throughout the disked profile of the occasional tillage field is attributed to increased loss through oxidation.

Actually, the cropping sequence in the occasional tillage field, with no soybean in the crop rotation, is assumed to

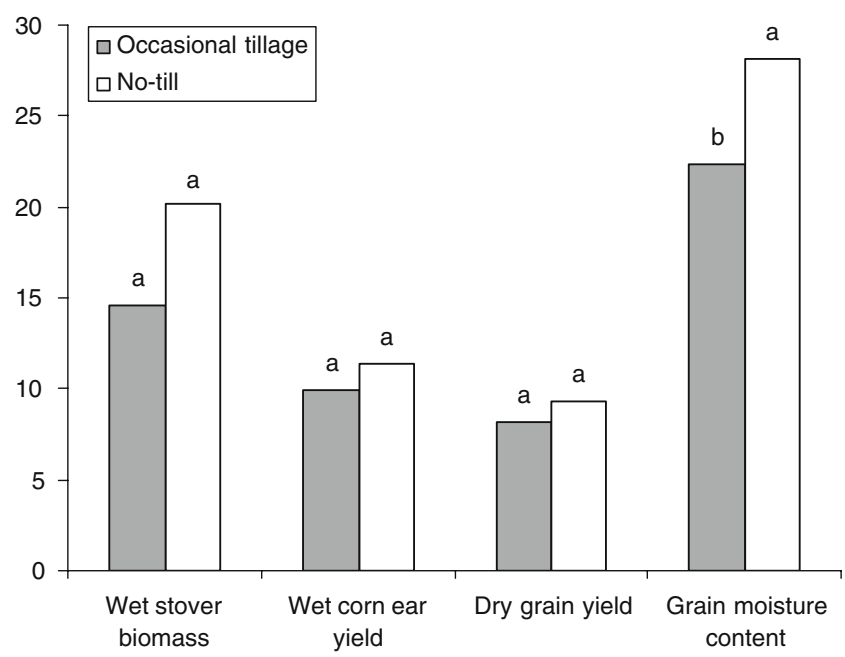

Fig. 3 Mean wet stover biomass $\left(\mathrm{Mg} \mathrm{ha}^{-1}\right)$, wet corn ear yield $\left(\mathrm{Mg} \mathrm{ha}^{-1}\right)$, dry grain yield $\left(\mathrm{Mg} \mathrm{ha}^{-1}\right)$, and grain moisture content $(\%)$, according to treatment. Means within a pair of bars followed by different letters differ at the 0.05 probability level according to Tukey's HSD 
increase the amount of organic residues retained in situ as compared with the no-till field, which had two consecutive years of soybean prior to the studied season's corn crop. Also, the manure application in the occasional tillage field was favorable in this regard as compared with the chemical fertilizer used in the no-till field (Table 1). Thus, the actual negative impact of the occasional tillage on soil organic carbon concentration was assumed to be even larger than the detected, as both the cropping sequence and manure application in this field may have compensated for some of the losses by oxidation. The higher soil organic carbon concentration in the no-till field increased soil aggregation and decreased the soil bulk density. These effects were evident by the high and very significant positive correlations between the soil organic carbon concentration and mean weight diameter of aggregate $(r=0.50, P<0.0001)$, and by the high and very significant negative correlations between soil organic carbon concentration and bulk density $(r=-0.55, P<0.0001)$.

\subsection{Crop yield}

Despite a non significant effect of tillage treatment, the mean values of wet stover biomass, wet corn ear yield, and dry grain yield were somewhat higher in the no-till field than those in the occasional tillage field. The mean grain moisture content was significantly higher under no-till than that under occasional tillage (Fig. 3). The adverse effect of the occasional tillage on any of these agronomic indices may be attributed to the crust formation under this treatment, which reduced water infiltrability and thus, decreased the availability of water for the corn plants. Also, the reduced soil physical quality and the decreased soil organic carbon concentration were expected to negatively affect crop production in the occasional tillage field. An alternative explanation was suggested by Cassel et al. (1995), who noted that high mechanical resistance of the soil surface can cause injury to seedlings during emergence through the mechanical crusts, resulting in decreased seedling germination and development. Future studies are needed to examine the impact of occasional tillage within long-term no-till agroecosystems on crop yields. This has to be done in order to determine the mechanisms that affect soil fertility and crops productivity.

\section{Conclusion}

Compared with prior studies which examined the effects of continuous no-till and occasional tillage under research station conditions (Pierce et al., 1994; Kettler et al., 2000; Quincke et al., 2007a,b), the present study was conducted under on-farm conditions. Wherever possible, on-farm studies should be preferred because they better represent the natural- and management-induced variations. These variations do not occur in standard research plots, and can result in difficulties to extrapolate the data to the field scale. Indeed, the cropping sequence and fertilizing methods in the two fields of the present study were not identical. Nevertheless, the cropping sequences were relatively similar, and considering the extremely large spatial variability in terms of bedrock, topography, and soil series in the study region, the selected fields were the quite similar. Thus, they were suitable cases for such an on-farm assessment.

Although the differences were not significant for all the tested variables, the results presented supported the conclusion that even one year of tillage following continuous no-tillage can adversely impact the soil quality. The occasional tillage negatively affected key soil properties, including penetration resistance, bulk density, aggregation, water infiltrability, field moisture capacity, and organic carbon concentration. The actual effect of occasional tillage on the soil quality was assumed to be even stronger than that observed, but it may have been mitigated by the application of poultry manure in the occasional tillage field before the growing season. Also, visual observations revealed the formation of mechanical crusts following the occasional tillage. The modifications in the soil quality and surface characteristics may have negatively impacted crop yields. These changes illustrate the ease by which the degradation processes caused by occasional tillage can occur, and contradict the study hypothesis.

Yet, it is agreed that the impact of occasional tillage on soil characteristics and crop yields may be site-dependant and determined by a range of physical and biological conditions. Additional research is required to examine the effects of occasional tillage in continuous no-till agroecosystems in order to assess its impact on both soil and crops under diverse natural conditions and management practices.

Acknowledgments The research was funded by the Midwest Regional Carbon Sequestration Partnership (MRCSP). We kindly acknowledge Mrs. Joyce Alloway and Mr. Don Lightell for the helpful assistance in field and laboratory works. We are grateful to Mr. Abe Miller and Mr. Malvin Yoder for allowing access to their fields.

\section{References}

Bajracharya RM (1995) Soil crusting and erosion processes on an Alfisol in south-central India. The Ohio State University, $\mathrm{PhD}$ dissertation

Blanco-Canqui H, Lal R (2007) Soil and crop response to harvesting corn residues for biofuel production. Geoderma 141:355-362. doi:10.1016/j.geoderma.2007.06.012

Blanco-Canqui H, Lal R, Post WM, Izaurradle RC, Shipitalo MJ (2006) Organic carbon influences on soil particle density and 
rheological properties. Soil Sci Soc Am J 70:1407-1414. doi:10.2136/sssaj2005.0355

Bono A, Alvarez R, Buschiazzo DE, Cantet RJC (2008) Tillage effects on soil carbon balance in a semiarid agroecosystem. Soil Sci Soc Am J 72:1140-1149. doi:10.2136/sssaj2007.0250

Bradford JM, Remley PA, Ferris JE, Santini JB (1986) Effect of soil surface sealing on splash from a single water drop. Soil Sci Soc Am J 50:1547-1552

Cassel DK, Raczkowski CW, Denton HP (1995) Tillage effects on corn production and soil physical conditions. Soil Sci Soc Am J 59:1436-1444

Fan Y, Lei T, Shainberg I, Cai Q (2008) Wetting rate and rain depth effects on crust strength and micromorphology. Soil Sci Soc Am J 72:1604-1610. doi:10.2136/sssaj2007.0334

Grossman RB, Reinsch TG (2002) Bulk density and linear extensibility. In: Dane JH, Topp GC (eds) Methods of soil analysis, Part 4. Soil Science Society of America, Madison, WI, pp 201-225

Institute SAS (1990) SAS/STAT user's guide, Version 6, 4th edn. SAS Inst, Cary, NC

Kelley GE, Edwards WM, Harrold LL (1975) Soils of the north Appalachian experimental watershed. USDA, Washington D.C

Kettler TA, Lyon DJ, Doran JW, Powers WA, Stroup WW (2000) Soil quality assessment after weed-control tillage in a no-till wheat-fallow cropping system. Soil Sci Soc Am J 64:339-346

Lal R, Griffin M, Apt J, Lave L, Graner Morgan M (2004) Response to comments on "Managing soil carbon". Science 305:1567-1568

Martinez E, Fuentes JP, Silva P, Valle S, Acevedo E (2008) Soil physical properties and wheat root growth as affected by no-tillage and conventional tillage systems in a Mediterranean environment of Chile. Soil Till Res 99:232-244. doi:10.1016/j.still.2008.02.001

Moebius-Clune BN, van Es HM, Idowu OJ, Schindelbeck RR, Moebius-Clune DJ, Wolfe DW, Abawi GS, Thies JE, Gugino BK, Lucey R (2008) Long-term effects of harvesting maize stover and tillage on soil quality. Soil Sci Soc Am J 72:960-969. doi:10.2136/sssaj2007.0248

Neave N, Rayburg S (2007) A field investigation into the effects of progressive rainfall-induced soil seal and crust development on runoff and erosion rates: the impact of surface cover. Geomorphology 87:378-390. doi:10.1016/j.geomorph.2006.10.007
Nelson DW, Sommers LE (1996) Total carbon, organic carbon, and organic matter: laboratory method. In: Sparks DL et al (eds) Methods of soil analysis, part 3. Soil Science Society of America, Madison, WI, pp 961-1010

Nimmo JR, Perkins KS (2002) Aggregate stability and size distribution. In: Dane JH, Topp GC (eds) Methods of soil analysis, part 4. Physical methods. Soil Science Society of America, Madison, WI, pp 317-327

Philip JR (1957) The theory of infiltration: 4. Sorptivity and algebraic infiltration equation. Soil Sci 84:257-264

Pierce FJ, Fortin MC, Staton MJ (1994) Periodic plowing effects on soil properties in a no-till farming system. Soil Sci Soc Am J 58:1782-1787

Quincke JA, Wortmann CS, Mamo M, Franti T, Drijber RA (2007a) Occasional tillage of no-till systems: carbon dioxide flux and changes in total and labile soil organic carbon. Agron J 99:11581168. doi:10.2134/agronj2006.0317

Quincke JA, Wortmann CS, Mamo M, Franti T, Drijber RA, García JP (2007b) One-time tillage of no-till systems: soil physical properties, phosphorus runoff, and crop yield. Agron J 99:1104-1110. doi:10.2134/agronj2006.0321

Reynolds W.D., Elrick D.E., Youngs E.G. (2002) Ring or cylinder infiltrometers (vadose zone). In: Dane J.H., Topp G.C. (Eds.) Methods of soil analysis. Part 4. Physical methods, Soil Science Society of America, Madison, WI,USA; pp. 818-820

Shukla MK, Lal R (2005a) Erosional effects on soil organic carbon stock in an on-farm study on Alfisols in west central Ohio. Soil Till Res 81:173-181. doi:10.1016/j.still.2004.09.006

Shukla MK, Lal R (2005b) Erosional effects on soil physical properties in an on-farm study on Alfisols in west central Ohio. Soil Sci 170:445-456. doi:10.1097/01.ss.0000171667.60883.f2

USDA-NRCS. (2002) Soil survey of Coshocton County, Ohio

Wells RR, DiCarlo DA, Steenhuis TS, Parlange JY, Römkens MJM, Prasad SN (2003) Infiltration and surface geometry features of a swelling soil following successive simulated rainstorms. Soil Sci Soc Am J 67:1344-1351

Zeiger M, Fohrer N (2009) Impact of organic farming systems on runoff formation processes - a long-term sequential rainfall experiment. Soil Till Res 102:45-54. doi:10.1016/j.still.2008.07.024 